\title{
Research on the Innovation of Teaching Management System in Colleges and Universities for Training Applied Talents
}

\author{
Yuzhen Wang ${ }^{a}$, Rengui Zhao ${ }^{b^{*}}$ and Chundi Zhao ${ }^{c}$ \\ 2888, Xincheng Street, Changchun, Jilin Province 130118 P.R. China \\ a349835300@qq.com, b2992807490@qq.com, '605395854@qq.com \\ *The corresponding author
}

Keywords: Applied talents; Colleges and universities; Teaching management system; Innovation

\begin{abstract}
The research on the innovation of teaching management system in Colleges and universities can effectively promote the improvement of teaching management system. For the cultivation of Applied Talents in Colleges and universities, it is still in its infancy, so it is necessary to innovate the teaching management system. In order to cultivate applied talents in Colleges and universities as the research object, the existing research on teaching management system, and puts forward corresponding countermeasures.
\end{abstract}

\section{Existing Teaching Management System of Colleges and Universities to Cultivate Applied Talents of the Problem}

To cultivate applied talents in Colleges and universities, because in the early stages of development, so there are many problems in the teaching management system, mainly reflected in the following four aspects.

Backward Education Concept. Modern education pay attention to "people oriented", which means that students have the right to know, choose the right to receive education, and so on. The so-called right to know, students have the right to know the relevant system, development direction and those students and its related activities, according to the information they are aware of the initiative to participate in the teaching management and the teaching activities of rights. The so-called option, refers to the students for their own courses and teachers have the right to choose their own. Although the education idea of "people oriented" have existed for a long time, but from the specific implementation is still a big gap and many colleges and universities simply does not exist "people-oriented" philosophy of education, which is nothing more than a verbal slogan. In terms of the right to know, many colleges and universities do not pay attention to, so students can not participate in the teaching management system. As far as the option is concerned, most of the colleges and universities are directly to help students to develop curriculum and choose the teacher, as for the students themselves, there is no independent choice of the right. On the one hand, most of the colleges and universities in our country are the credit system teaching management, if allowing students to choose their own courses, it would lead to the difference of high and low credit and professional core courses, students are not necessarily interested in; On the other hand, the college teachers are not enough, so they do not allow students to choose their own courses and teachers. Although college students can choose elective courses, but can choose a limited range, can be said to be within the scope of the provisions of choice.

Defects Exist in the Mode of Talent Training. For colleges and universities, it is necessary to develop appropriate personnel training mode, but there are many defects in the training mode of talents in Colleges and universities. The so-called applied talents, refers to the theoretical knowledge and practical ability, which is in line with the needs of modern society. However, in the University, in teaching very pays attention to the teacher's leading role, while ignoring the students as the main body of the right to choose, pay attention to the teaching content, but only in accordance with the standards prescribed by the state started teaching textbook, and despise the teaching method use. There is a very serious point is to pay more attention to the teaching of theoretical knowledge, but do not pay attention to the cultivation of practical ability. There is a very serious 
point is to pay more attention to the teaching of theoretical knowledge, but do not pay attention to the cultivation of practical ability. In such a talent training mode, the training of students has formed a set of thinking, and the lack of innovation and thinking ability.

In such a talent training mode, the training of students has formed a set of thinking, and the lack of innovation and thinking ability. Students are not able to or not dare to question to the teacher, and sometimes questioned also not encouraged, so for a long time down allows students to have no ability to think, lack of practical ability, lack of the courage to challenge and self-confidence, so that students are unable to grow into the talent. There is a phenomenon is very serious, that is on the textbook as the center of teaching, why would appear this kind of phenomenon, is because the current education assessment is still dominated by examination and test scores to decide the merits of a student, so to help students be able to pass the exam, the teacher will according to the textbook teaching. So that students can form a mindset.

The Education Autonomy Is Insufficient. For colleges and universities, the whole school is a whole, but under the school will be based on professional division of the College. Although schools and colleges are the main body of the teaching management, but the difference between the two levels, which makes it in the teaching management of the status and responsibilities are different. Because of the impact of the old system, so in the University, even if the use of the two level management system. But it is also very easy to produce a situation that is not clear in terms of responsibility and authority. It can be said that the education of the faculties of the autonomy is insufficient. On the one hand, the autonomy of colleges and universities is very small. In the teaching management of colleges and universities, subject teachers and teachers from in the Department, we can say it has the right to professional and curriculum, has the right to develop the teaching plan, have the right to choose the appropriate teaching method, have the right to develop appropriate standards of teaching evaluation, when necessary, can also be carried out the reform of curriculum. But in practice, Faculty very easily by the restriction of university system, have rights and recognition of responsibilities between the two don't match, especially in teaching management and teaching reform, college is not to speak of the rights, so that the Department of autonomy, enthusiasm and creativity greatly weakened. On the other hand, the investment in practice teaching management is a serious problem. Our country began to promote the construction of Application-oriented Colleges and universities is not a very long time, is still in the initial stage of construction, so it should be a lot of investment funds for support. However, the actual investment funds are limited, and natural inputs to the practice of teaching management funds also exist gap.

The Quality of Practical Curriculum and the Deficiency of Mathematics and Physics. To cultivate applied talents of colleges and universities, the creation of the curriculum practice, but in practice course of quality and quantity there is still insufficient, which makes students choose range is severely reduced, many students for the course opened practice wasn't interested in it. First of all, the practice curriculum needs professional instructors, but universities have practical ability of teachers is the number of less and some even chooses to study substitute. Not to mention the enrollment expansion of colleges and universities, the proportion of students and teachers is not coordinated, the practice of the course cannot meet the needs of all students. In particular, the selection of courses, the number of elective, then only a small number of students can participate. Secondly, to open a new practical course, it must be completed by the first line teachers. The number of first-line teachers in Colleges and universities has been limited, coupled with the front-line teachers focus on research, and even most of the experience is put in the scientific research, so that more cannot be opened a new practical courses. It is because of these reasons, resulting in the practical courses either in quality or quantity is seriously inadequate, unable to meet the needs of the students, naturally unable to cultivate students' practical ability, to make it grow for applied talents. 


\section{Research on the Innovation of Teaching Management System in Colleges and Universities for Training Applied Talents}

To solve the existing teaching management system in Colleges and universities to cultivate applied talents for the problem, we should reform and innovation.

Highlight the People-Oriented Teaching Management Concept. As saying goes, thought determines action. From human development to the present, no matter what a great revolution, it is the first to have the concept of thinking and then pay the actual action, thus promoting the progress of human society. Therefore, for the training of Applied Talents in Colleges and universities is so, only in the premise of teaching management idea of "people-oriented" and to the "people-oriented" spirit and content in practice. For college education, with the "people-oriented" teaching management concept, we should put the students in the dominant position of teaching, according to the needs of students and the characteristics of the teaching work. Training applied talents in Colleges and universities is to cultivate the applied talents as the goal. Students should become the main body of teaching.

Give Students the Right to Know and Choose the Right to Know. Many colleges and universities lack the right to know and choose the right to choose, long-term is not conducive to the development of students, this should give students the right to know and the right to choose, so that they have autonomy in teaching management. Generally speaking, students in Colleges and universities for schools to develop teaching plans, training schemes, rules and regulations, curriculum arrangement, teacher qualifications, the educational and teaching activities related to the project has a certain right to know and right to choose. So in reality, how to give students the right to know and choose the right to choose? Giving the right to know can start from three aspects: First, the timely update the school website, in the website of the school above school affairs, and as long as it is and student related information should be released on the school website, and guide the students to actively to what happened in the relationship between school and schools to develop policies, rules and regulations; Secondly, monitor to play the role, once or school is a college what activities associated with the students, should be timely contact monitor, and to monitor to convey to students, can use micro letter group, QQ group chat tools, more convenient; Finally, students can actively to the counselors, teachers, and so on to understand the situation. Given the choice, we should let the students choose a professional and give students some turn professional opportunities, of course, turning professional to choose in the freshman or sophomore year, does not affect the professional course learning; Secondly, after the selected professional, can choose their own courses, every profession has different direction, different subjects can learn every direction, so the students can choose their own, and you can choose to choose courses teachers; Finally, choose to study life, each student's learning ability are different, so as long as it is stipulated in the credit, and students can completed specified credits, then regardless of their learning time length, should run the graduation.

Improve the Autonomy of Departments and Departments in the Field of Education Management System. Although the University and college level is two different levels, and university level to college level higher than the, but in the practice of university teaching management and the concrete implementation or hospital level, so it should be improvement of hospital level in education management system autonomy. First, the college should be set up properly. Each university's situation is different, the focus of teaching subjects is also different, so it should be based on their actual situation to set the college. After setting the college, should be in accordance with the direction of the development of colleges and universities to develop long-term development goals and short-term development goals, and do a good job in overall planning. Second, clear the needs of the society. The purpose of training applied talents is to make it more quickly adapt to the society, people cannot be divorced from the society, so the work can never keep up with the rhythm of the society. Colleges should look to the community, the market demand for each industry, and enterprises to establish a good relationship, so as to cultivate a more applied talent. Third, increase the investment of funds. To research on the innovation of the teaching management system, then it is necessary to use the funds. Therefore, in addition to the receiving 
state funding should the income generated part is devoted to the study, especially to increase the funds in practice. Fourth, expand the practice of teaching management. Theory needs to be verified through practice, a lot of college teachers themselves on the lack of practical ability, so how can we educate the students? For these teachers, should expand the training, so that it can combine the work experience and practical ability, do a good job in teaching management.

Perfecting the Course Selection System. For students in Colleges and universities, the present stage is the implementation of the credit system, and the implementation of the credit system is the premise of the elective system. The elective system of course is not to let the students chosen at random, but within a certain range to choose, on the one hand, give the students the freedom to choose the right, on the other hand also makes the choice of students around the professional needs. In terms of colleges and universities, we should improve existing elective system, perfect the practice of elective courses, both to improve practice elective course of quality to increase the number of, so that a student's choices is much broader. In addition, it should also strengthen the guidance for students to choose, to choose a more suitable for their own courses.

Constructing the Evaluation System of Practical Teaching. The effect of practice teaching management is how to evaluate the teaching work of the teachers, so the university should establish the evaluation system of practical teaching. First of all, should choose a suitable evaluation of people, in the choice of the time, in order to professionals based, try to avoid let nonprofessionals to participate in the evaluation. For those enterprises to cooperate with the practice of the project, you can also choose to allow enterprises to evaluate. Secondly, we should choose the appropriate evaluation criteria, in the evaluation of the time, the need to get the final results by one index, the selection of the evaluation index is very important. The selection of evaluation indicators should be open, with a certain flexibility. In addition, should also take into account the achievements of scientific research have been completed, is not already applied to the teaching of. Then the teaching can keep pace with the times, timely update the scientific research, scientific research methods and so on.

In summary, for training applied talents of colleges and universities teaching management system in terms of, it is very necessary to innovate, because only through innovation, to modified at this stage in the teaching management system existing problems, more in line with the cultivation of applied talents of colleges and universities teaching management system, for the society, to train more applied talents for the country, to promote the further development of our country.

\section{References}

[1] Xu Qi, Research on the innovation of teaching management system in Colleges and universities for training applied talents [J], Statistics and Management. (2015) 12:157-158.

[2] Li Juan, Innovation of teaching management system in Colleges and Universities Based on innovative talents training [J], Management. (2014) 35:322.

[3] Yan Dong, Li Yanlin, Innovation of teaching management system in Colleges and Universities under the concept of innovative talents training [J], China off campus education. (2014) S3:221.

[4] Lin Yanfang, Innovation of teaching management system in Colleges and Universities Based on innovative talents training [J], Asia Pacific Education. (2015) 21:243.

[5] Sun Donghui, Innovative talent training concept of college teaching management system innovation [J], China Adult Education. (2015) 14:41-42.

[6] Zhou Lianfang, College Teaching Management Research Based on innovative talents training [J], Journal of Kaifeng Institute of Education. (2010) 04:51-53.

[7] Jin Lu, Reform of college teaching management reform based on the cultivation of innovative talents [J], Higher Education Development and Evaluation. (2008) 06:34-38+121-122.

[8] Liang Xiushan, on the teaching management innovation of Applied Talents Cultivation [J], 
Contemporary Education Forum (Principal Education Research), (2008) 08:32-34.

[9] Pan Di, Li Youcheng, under the background of the reform of teaching management of [J], Education Forum training innovative talents. (2013) 35:60-62.

[10]Xiao Chunlan, Discussion on the teaching management in Colleges and universities in training applied talents in the orientation and implementation $[\mathrm{J}]$, Modern marketing (Academy version). (2012) 05:260-261.

First Author: Wang Yuzhen Unit: Jilin Agricultural University Second Author: Zhao Rengui Unit: Jilin Agricultural University

Fourth Author: Zhao Chundi Unit: ChangChun University of Science and Technology 